\title{
2. EMPATHY AND COMMUNICATION THROUGH ART
}

Marinela Rusu ${ }^{58}$

\begin{abstract}
Art is one of the finest means of shaping the personality, of access to aesthetic and moral values of society. The paper presents some of the elements of communication through art, in the double sense of this process, from the artwork (creator) to the viewer, but also from the viwer to the work of art and creator. The key-element of this dual process is the empathy, the ability to feel the emotional states of others. It develops within a set of personality traits, including: emotional intelligence, emotional feelings diversity, cognitive skills, along with motivation and personal ideals. Art is a medium of communication but also an element of developing a general receptivity to the world and its authentic values.
\end{abstract}

Key words: art, communication, empathy, creativity, art receptor, aesthetic judgment

\section{Emotional feelings and empathy}

Empathy, being a component of emotional intelligence domain, is the cornerstone of any attempt to optimize psychological self-awareness and relationships with others. Without empathy world would be a dull world, a place of autism and emotional schizophrenia. "We are spiritually rich, writes S. Marcus (1997, p. 80), only to the extent that we can enrich ourselves with empathic experiences, and we gain the depth of spiritual understanding only when we come to truly understand those around us." Interactions with others put often in discussion the empathic abilities that we have, revealing how well we know and understand those around us, without resorting necessarily the a verbal communication. The way we infer someone else's feelings also implies the ability to interpret nonverbal channels: tone of voice, gestures, facial expression, body posture, arms etc. In general, women are more careful about this kind of perception.

In C. Rogers's words, "being empathical means to perceive the internal reference of another, with all its emotional components and meanings, as being the other person but without losing the consciousness of <like as >." (Rogers, 1966, p. 54). In the simplest terms is the ability to put oneself in another's place, to see and feel the world as he feels. Daniel Goleman (2004) repeats the assertion made by Martin Hoffman, that the roots of morality should be sought in empathy because, participating in someone's pain, we feel the urge to help. Empathy not only makes us more understanding, loving and caring in our family relationships, emotional or job relationships etc. but helps us become compassionate beings for those who we do not know and learning about their sufferings, we will try to help somehow. Empathy submit to our attention the social problems and injustices that lead us to take a stand and thus, those social problems become our problems.

\footnotetext{
${ }^{58}$ Researcher PhD. and visual artist / Romanian Academy, Institute "Gheorghe Zane" from Iași Branch, Romania, email: marinela1808@yahoo.com
} 
The work of art has the ability to capture important aspects of the ontogenetic development of human history also as a group, multiculturally diversified. It can be said that art is an essential element without which consciousness would not have evolved, bringing the human being what it is today. As well-known psychologist Ursula Schiopu observes, "art brings us the existential essence significance. The work of art creates a bridge (moments of emotions and feelings of exception) between one who possesses the ability to create and which has incorporated it in creation, and the man who contemplates the work of art and loads of its anguish and its surface or depth messages. This meeting has the characteristics of a particular empathy process, full of associations that makes a subjective contemplation and context of intentions, emotions, fervor, restlessness, exposed, explicit or latent in the artwork, which can be a painting, a sculpture, a palace, a concert, an opera or theater etc." (Șchiopu, 1999, p. 3). Any artistic creation carries a coded message which gives to society complexity, depth and the possibility of developing new informationtional universes. This will outline individual preferences influenced both by the degree of culture, sensitivity and personal ideals. Art is constituted as a moment of greatness of man, a relative and ephemeral moment.

Art studies are relatively recent and deals with areas such as art history, philosophy, psychology, sociology and pedagogy of arts and, of course, aesthetics. We can analyze art from different perspectives, precisely because it is an expression of our culture and civilization. For example, psychology, addressing psychological processes, personality and human behavior added to its studies the psychodiagnosis of creativity and developed arts psychotherapy. "Problems of creativity, writes U. Şchiopu, of development and stimulation of creativity, are particularly important, as they are the support of the human condition and progress as they engage in the task of detecting, stimulating and protecting highly creative people, to help the human of future centuries ridding of sclerosis and erosion of non-values and devaluation of man, whose constructive chances grow through creativity." (Idem, p. 9). Creation is a complex process in which is maximum enabled not only the creative intelligence of the artist but also the active spectator, which validates the opportunity to talk about a psychology of art reception, of contemplation or consumption of art and one of the values implied in the circulation of social art.

\section{Aesthetics}

Concerned by centuries of understanding and defining the concepts of beauty and ugliness in art, aesthetics is an area that often intersect with philosophy and morals. One can speak of a relationship between ethics and aesthetics which, gives contemporary art a possibility of a generous manifestation. Aesthetics is the analysis of evaluative judgments appreciation and operates mostly with differentiations of ugly/ beauty. Because aesthetic value judgment studying in principle, the artist and the viewer, and even the artwork as a whole, they are only taking the perspective of evaluation. By this, aesthetic is a normative science, akin to the logic and morality. Psychology of 
art, however, focuses on complex existential experiences of the artist and of the art receiver. The act of creation is a complex process with a deep personal involvement. It mediates the communication of desires, attitudes, fears but also promotes expression of him/herself that needs to be understood and respected through proper conduct of rank and social status. All these demonstrate a culture and a civilization that feeds a sociology of art, emerging differently in different parts of the world, filled with specific characteristics, but also with a theme somewhat universal, about the history of human evolution (Rusu, 2015a, 2015b, 2016). Sometimes, individual ideals confound with the ideals of a society, with its mentality or tragedies (eg. Fig. 1-2 - E. Delacroix, Liberty, Ellada on the ruins of Missolonghi, fig. 3 - P. Picasso, Guernica, fig. 4 - Jean Louis David, The Death of Socrates). Culture incorporates into its structures different sides of creativity (attitudes, skills, talents, affective states), but gives, on the other hand, some investigating stimulation, force to push, communicate, cipher and decipher, to symbolize the dimensions of life and events and to fit them with infinite shades of emotional states. Artwork condenses multiple existential values and embraces a micro-existence of human uniqueness.

Through art, the human mind has shaped and shapes its structures and nuanced feelings of depth and spatial/temporal variability, of demiurgical implication. Horizontally, it gathered subtle forces in the course of time, latent complex accumulations, which palpitate, on the one hand, in the spirit of creators and on the other hand, in the spirit of the culture of the time. They crystallize in a sensitivity that has relatively different structures, as attitudes towards art, involved in inner psychic forces; through them it creates a psychic ability and outstanding responsiveness, to seek, know and design the interior fever, related to art and the need for it.

Intense emotions characterize the meeting with art, boosting the intellect, the behavior and sometimes the creativity, and represents one of the results of art reception. The artistic product itself, synthesize, in turn, subjective intense experiences, constituting mirrors of a moment and also becoming unpublished archives of a social subtext, as the theme, work style and other attributes allow us to recognize the time in which lived the creator of the artwork. This means that the artistic product condenses different information and knowledge on universality and timeliness of a section of the social and cultural life.

\section{The Contemplator}

Art has always described man's struggle, eternal and hard between good and evil. J. B. Molière's theater, Shakespeare's tragedies highlight this phenomenon and Roman sculptures differ from those of the ancient Greeks, in the types of behavior and feelings they express. There is a historical evolution of human themes and dilemmas described in all kinds of artworks. Lev Tolstoy observed that the artwork can affect its creator, calling this phenomenon "contamination": "I was contaminated with typhus from Ivan, he says, ...but I'm sick of my typhus and not of Ivan's typhus and Hamlet that I carry in me is mine and not Shakespeare's" (cited by Jeane Segal, 1999, p. 54). Art gives thus the 
possibility to redefine the artist's personality being a means of personal development through self-knowledge. These experiences enrich the human psyche, making it more complex, capable of understanding and adapting to daily live. Artistic experience, the reception of art represents the pleasure of a new experience, through which the individual acquires a more complex experience, more condensed and with more meanings and significations in a short time, but which "expands inside, adapting to the dimensions of the universal time " (Salovey \& Mayer, 1990, p. 118).

Psychology of art took a cohesive identity after Henry Delacroix published his work entitled "Psychology of art" (1927). In the romanian foreword signed by O. Barbarossa, we fiind an eulogy for the humanist approach of this work, removing the art analysis from the monopolizing areas of aesthetics, restoring its humanist optics related to the creative forces of man and its social and historical influences. Through this work psychology distanced of aesthetics, an inevitable process by which ideation and philosophical theories distanced themselves from a wide area, that of creation (as a complex process conditions, stimulating factors, effects) and that of artist's personality (biographical aspects, social and cultural integration, psycho-affective and creative capabilities).

According to Delacroix's optics, art serves - metaphorically speaking - to reflect reality, converting it into a state of reception, as a kind of vision, says the author, with complex functions, among them being that of becoming one of the means through which man attains self-unification toward an exceptional experience. In this context, "the work of art produces vibration, sensitivity and reason, not just in the act of creation but also through the contact with the works of art." (Delacroix, 1927). In this latter approach, Delacroix reached a very hot problem, discussed in years 1930, which was later developed by Schiller; in summary, is the idea that the game (very approached by its great importance on mental development in childhood) constitues the base in art creation. Delacroix notes that art process condenses toil and fatigue for a deep construction, so creating a clear distance between artistic creation and game. Associationists were those who had taken the problems of game involved in creation and not of creation involved in the game, as it happens in earlier periods of human life.

Delacroix looked at all the nuances of the game theory: the theory of excess of energy (Spencer) theory of game as pre-exercise (K. Gross), play as antidote of pleasure and its forms, game seen as a corruption of the meaning of infinity (paraphrasing Baudelaire), violent game, gambling, the game involved in irony, comedy and laugh (as an attitude of not taking seriously about a situation), and gossip, which (reminding M. Proust's opinion) exists behind reality and so on. Starting from the idea that there is a difference between action-game and game-dream, the author states that creative processes and reception of artwork, are neither diffuse nor momentary but complex processes loaded with special symbolism, lived with passion and dedication because the perception of art animates the universe and replace utility with visionary perception of things, generating a powerful virtual experience. Such an 
experience, however, is always confronted and eventually canceled by the reality and its chaos, facing virtualities of Ego and Non-ego. Meanwhile, Delacroix criticized the vitalistic theory for its reductionism (the basic idea being that unleashed creative energy serves only the will of living). Referring to Einfuihlung theory, Delacroix stressed the idea that artistic experiences are a way of opening the inner life of the human psyche to the outside world.

Delacroix has given to art different functions, as so-called "demiurgical". Artwork as well as moral action constitues a translation of the sensitivity of the spirit motion to its own sovereignty and fullness. Man has always wanted to be a transmitter of history and events that need to mark the syncope or the historical and social achievements and remain as exemplary image for the future generations. Writing, literature in this case, built the technological instrumentation of word-arts, whose power has grown exponentially over the centuries. We can not ignore that through writing, have been created a motivation for creative, artistic approach. The form of perception involved in contact with the artwork incorporates a great deal of intuition, which is anything but ordinary perception; it contains affective responsiveness, engagement of the capacity to find meanings, decoding messages, conversion of attitudes, aspirations and feelings of emotions, activated by the situational emotion. However, this form of perception, assume many skill-decoders and emotions of satisfaction and participation, conditioned by the structures of these constellations of skills in the living-contact with the artwork.

\section{Intuition and empathy}

After Th. Lipps (cited by Marcus, 1997, p. 182) the activated intuition - in contact with the artwork, facilitate an experience that has specific characteristics. In his view, there are four kinds of empathy. The first is a general empathy, aperceptive, which is the support of the perception that any process includes in its structures a special activity, that has a communicationside of the man who created the object. Generally, the idea of involving personal characteristics in everything one does is the expression of one who has performed the design of an object. The second form is the empirical or natural empathy, expressed in the appreciation that the artistic object has force and motion, expressing a feeling, which employs a kind of anthropomorphism. But this is different from primitive anthropomorphism, being rather an expression of the meeting between previous and recent states, plus the contact with art (stratified contact in personal experience).

A third form is dispositional empathy generated by the artwork (warm or cold colors, serious, sad, happy, thoughtful figures, etc.), which engages in dispositional, ground of the art work contemplator. The last form of empathy is Ego transposition empathy within the meaning and significance of the messages highlighted by the artwork, provided by the creator in his artistic product. Aesthetic empathy is close to the latter form of empathy described by Lipps. All forms of empathy develop and become more complex, depending on life 
experience, in art case, or interest in art, influenced by the contacts generated by interest.

As such, empathy involved in the contemporary work of art has an active, anticipatory implication of potential reactions, behaviors and emotions of the characters involved in the work of art. The contemplator can anticipate reactions directly and indirectly to created situations and interrelations. All this shows that empathy is richer and more prolific even than the perception and observation. Pavelcu V. (1982) also made interesting comments on empathy, that becomes very active, especially in limit, dramatic situations presented in an artwork. E. H. Gombrich (1973) emphasized that in empathy occurs a kind of mental symbiosis that is part of emotional states, while S. Marcus \& Doina Săucan Stefana (1994) and Al. Rosca (1981) considered empathy as a particularly complex psychological state and brought it out from the seconds plans where was pushed by the orthodox behaviorism and somewhat less by the neobehaviorism.

M. E. Sourian in his work L'Avenir de l'Esthetique (1929) in the controversial dialogue with Basell (Essai d'Esthetique) considered that empathy is developed more in aestheticians and artists than in people who have other kinds of occupations. We could consider that in the contact with art, feelings and empathy creates tensions and the artist included in his art a message and a potential sequence of his life. Artwork causes empathic mental states which are different for temporal arts and for spatial arts, an emotional-intellective domination, provocative of meditations, in spacial arts, and empathy that condenses, while carrying the art sequences, intense feelings that are consumed in an interior film, unfolded with much greater speed than the one caused by the current events of life and creates premonitional replicas, more powerful than those of everyday life.

And one more thing: art leads through the forms of empathy that it causes, the human force of being there where is not, perceiveing that space and time, transmitted by the creator. The idea is that, as stated by Gh. Neacşu, "psychic, affective experiences, involved in contact with works of art are consumed at a higher voltages than usual." (Neacșu, 1999). The author also recall in his study, the research conducted by C. Enăchescu, where plastic expression is seen as a "form of externalization of intrapsychic content of personality, having the same value as oral language or writing for intrapersonal communication process" (Idem, p. 10). Specifics of the work of art lies precisely in the fact that the creator mediates the contact with his audience, and its structure, carrying potential meanings, creates subjective states corresponding to receptors being in an indirect relationship with the object represented or suggested.

\section{Conclusions}

The work of art has an identity that makes it unmistakable with others, even if they are products of the same artist. This individuality, unmistakable of artistic creations led to appreciation of the artwork as unique. The paradox of an art work is that, although it is a singular expression of individuality, which 
concentrates in itself a typical substance of a certain social generality, precisely this interpenetration makes it polysemics and having an open character.

Creator expresses himself, but also succeeds in this value intersection between his feelings, personal experience and the feelings and experiences of others who are more or less, similar. The human dimension penetrate any creative product, which expresses us as a race, as a society or community. Art interfere with the personal values, those of the community and of the whole world also. Therefore, they are subject to the same degree in social, cultural and educational ideals. Universal and personal, become confounding dimensions of creation and thus, their value refers to personal modeling and development (Rusu, 2003).

In a poetical expression, Lucian Blaga says: "A work of art is always a dose of mystery, a sensitive revealing of unity and multiplicity, of meaning and irrationality, spontaneity, canonicity and originality ..." (Blaga, 1939, p. 125). Art is one of the most important answers that man gave to his existential questions, to the inner turmoil related to his condition in the world. And even if there it is not a clear and definitive response, it continues - through myriad forms - to enrich our inner, emotional world, to help us in self-knowledge but also for a better knowledge of others.

\section{Bibliography}

1. Blaga, L. (1939). Artă şi valoare. București: Fundaţia pentru literatură şi artă.

2. Delacroix, H. (1927). Psihologie de l'art. Paris: Alcan.

3. Doncean, Gh. \& Doncean M. (2016). Ingineria creativității tehnice. Iași: Tehnopress.

4. Gombrich, E. H. (1973). Artă şi iluzie. București: Meridiane.

5. Goleman, D. (2001). Inteligenţa emoţională. București: Curtea Veche.

6. Marcus, S. (1997). Empatie şi Personalitate. Bucureşti: Atos.

7. Marcus,S. \& Săucan, D. (1994). Empatie și literatură. București: Editura Academiei.

8. Neacşu, Gh. (1999). Procesul de creaţie artistică (II). Perspectiva psihanalitică. Revista de psihologie, 1-2.

9. Pavelcu, V. (1982). Cunoaşterea de sine şi cunoaşterea personalităţii. Bucureşti: Editura Didactică şi Pedagogică.

10. Rogers, C. (1966). Le developpement de la personne. Paris: Dunod.

11. Roşca, A. (1981). Creativitatea generală şi specifică. București: Editura Academiei.

12. Rusu, M. (2015a). Inteligența emoțională - empatie și comunicare interpersonală. Iași: Universitas, Iași.

13. Rusu, M. (2015b). Intercultural Study of Art - Contemporary dimension. Review of Artistic Education, 9/10, 255-264.

14. Rusu, M. (2016). Artistic personality in the light of socio-cultural integration. Review of Artistic Education, 11/12, 209-220.

15. Rusu, M. (2003). Trăiri afective și compensări. București: Sophia. 
16. Salovey, P. \& Mayer, J. D. (1990). Emotional Intelligence. Imagination, Cognition and Personality, 9.

17. Segal, J. (1999). Dezvoltarea inteligenţei emoţionale. Bucureşti: Teora.

18. Şchiopu, U. (1999). Psihologia artelor. București: Editura Didactică şi Pedagogică.

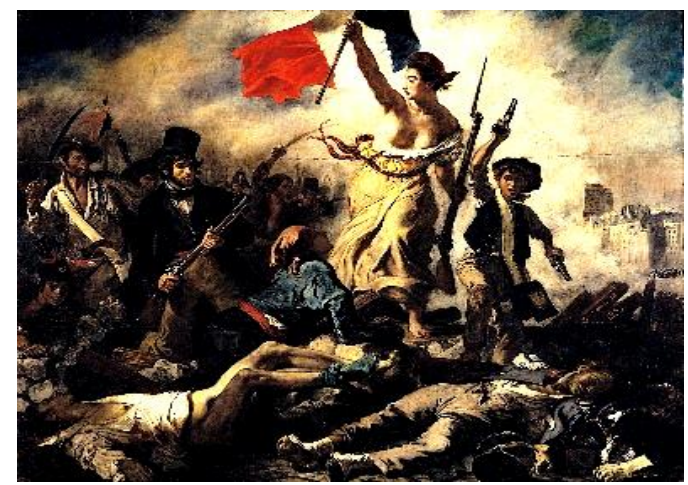

Fig. 1 - Eugene Delacroix, "Liberty"

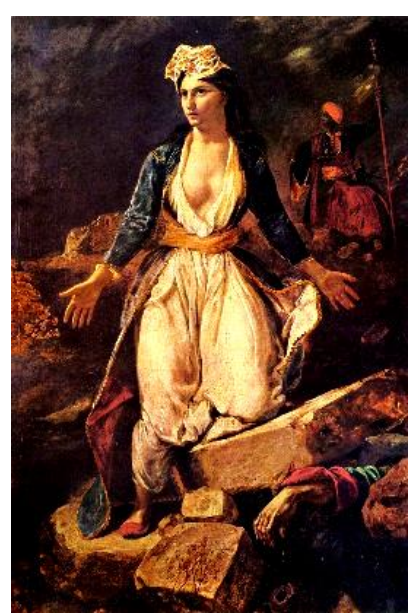

Fig. 2 - Eugene Delacroix "Greece on the ruins of Missolonghi"

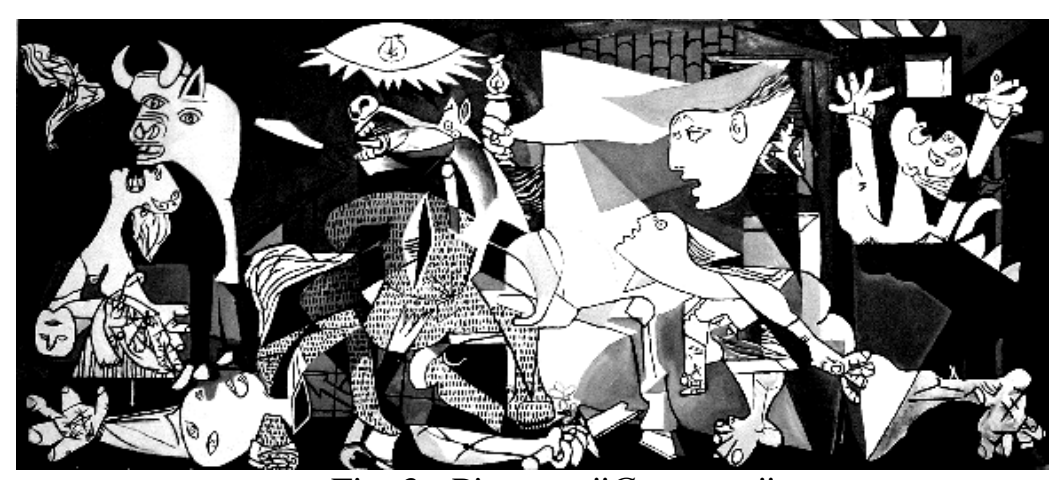

Fig. 3 - Picasso, "Guernica"

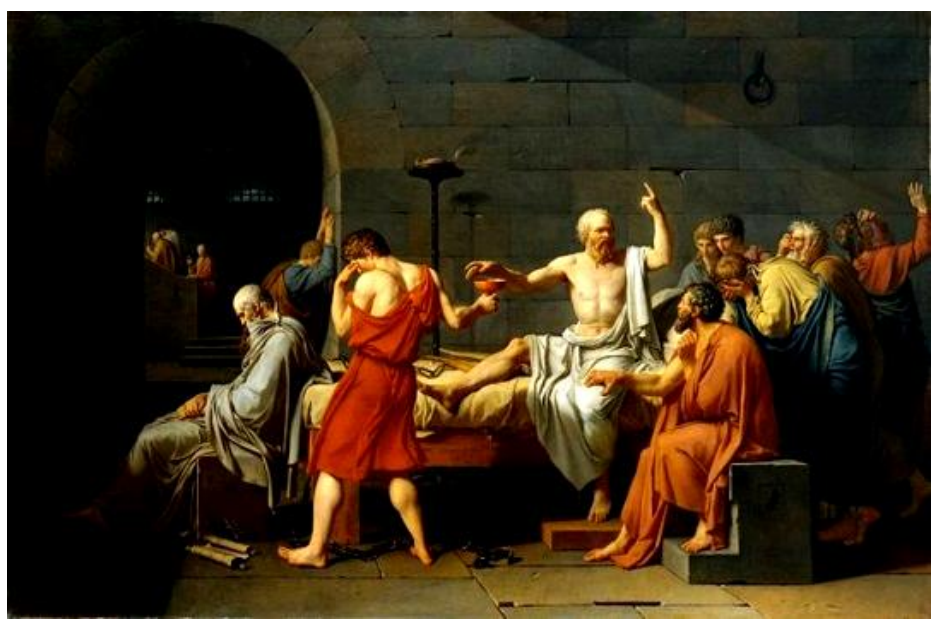

Fig. 4 - Jaques Louis David, "The death of Socrates" 